\title{
Образ войны в новеллах Мориса Дрюона
}

\author{
Ломоносова Ю.Е., Соболева Т.Е. \\ Белгородский государственный национальный исследовательский университет, \\ Россия, 308015, г. Белгород, ул. Победы, 85 \\ E-mail: lomonosova@bsu.edu.ru; soboleva@bsu.edu.ru
}

\begin{abstract}
Аннотация. Изучение универсального концепта «война» сквозь призму сознания писателя может способствовать пониманию принципов взаимоотношений между людьми в современном мире, и того, что в нем должно быть приоритетом, а также позволяет определить способы формирования нравственных ценностей посредством авторского слова и художественных образов. Несмотря на многочисленные исследования индивидуально-авторского концепта дискуссионными остаются вопросы о возможностях его структурирования с последующим выявлением своеобразия авторского стиля. Неоднозначность подходов к способам языковой и речевой репрезентации художественных концептов определила цель настоящей работы как моделирование системы художественных образов войны, отражающих особенности идиостиля французского писателя и его отношение к исследуемому социальному явлению. В процессе семантико-когнитивного и контекстуального анализа выявлены основные образные признаки концепта, представленные в произведениях Мориса Дрюона. Авторы отмечают, что индивидуальный ракурс концепт приобретает на уровне его языковой и контекстуальной репрезентации, что обусловлено мировоззрением писателя. Результаты исследования значимы с точки зрения овладения выразительными средствами французского языка для их использования в межкультурной коммуникации при выражении конкретной мировоззренческой позиции.
\end{abstract}

Ключевые слова: картина мира; художественная картина мира; индивидуально-авторский концепт; номинативное поле; образный компонент концепта.

Для цитирования: Ломоносова Ю.Е., Соболева Т.Е. 2020. Образ войны в новеллах Мориса Дрюона. Вопросы журналистики, педагогики, языкознания, 39 (4): 630-640. DOI 10.18413/27127451-2020-39-4-630-640

\section{Image of war in Maurice Druon's novels}

\author{
Yuliya E. Lomonosova, Tatyana E. Soboleva \\ Belgorod National Research University, \\ 85 Pobedy St, Belgorod, 308015, Russia
}

\begin{abstract}
The study of this universal concept through the prism of the writer's mind contributes to better understanding of human relationships' principles in the modern world, as well as makes it possible to identify ways to develop certain moral values by means of an authorial word and literary figures. In spite of the numerous studies that have been undertaken to investigate the individual author's concept, the questions on the prospects of its structuring with a view to identifying the author's style remain somewhat debatable. The ambiguity of approaches to ways of language and speech representation of artistic concepts has defined the purpose of the present work as modeling the system of the literary figures of the war reflecting the particularities of the French writer's style and his attitude to the social phenomenon being investigated. M. Druon's novels the stories of which take place during the Second World War have been the object of the present research. The cognitive-semantic and contextual analysis has identified the concept's figurative component features characteristic for the French writer's artistic worldview. The authors determine the composition of the nominative field of the individual author's «war» concept, analyze the contextual relevance of the linguistic means involved in the creation of the figurative
\end{abstract}


component and describe implicit and explicit figurative features of the concept. Special attention is paid to discovering the specificity of Druon's writing style characterized by the prevalence of metaphors, comparisons and abstract symbols. The results of the research are significant from the point of view of mastering the expressive means of the French language for their use in cross-cultural communication when expressing a specific ideological position.

Keywords: linguistic worldview; artistic worldview; individual author's concept; nominative field; figurative component.

For citation: Lomonosova Y.E., Soboleva T.E. 2020. Image of war in Maurice Druon's novels. Issues in Journalism, Education, Linguistics, 39 (4): 630-640 (in Russian). DOI 10.18413/2712-7451-2020-39-4$630-640$

\section{Введение}

Наличие взаимосвязи между чувственным опытом человека, мыслительными процессами, влияющими на формирование способности оценивать окружающую действительность и приобретать собственный образ мышления, с одной стороны, и способами отражения представлений о мире в художественных образах и языке, с другой стороны, является аксиомой в области культурологии и языкознания.

Одно из ключевых понятий данных направлений - «картина мира», определяемая как «совокупность знаний и мнений субъекта относительно реальной или мыслимой действительности, а также отраженные в языковых формах и категориях, текстах концепты, мнения, суждения, представления народа, говорящего на данном языке, о действительности, об отношении человека к действительности» [Азимов, Щукин, 2009, с. 91]. По мнению Ю.Д. Апресяна [1995, с. 350], картина мира исторически обусловлена, и поэтому ей свойственны постоянные преобразования. Картины мира людей, принадлежащих разным этническим, религиозным, социальным сообществам, не идентичны, более того, даже в обществе, воспитанном на одних и тех же культурных ценностях, представления о мире отдельного взятого человека также имеют отличия. На основе картины мира и ее элементов формируется концептосфера каждого индивида, которая и определяет его поведение [Безрукова, 2000, с. 367]. «Каждый человек воспринимает этот мир по-своему, создавая свою субъективную карту - схему пространства и времени, в котором он живет. Эти различия детерминированы целым комплексом факторов - от психофизиологических и индивидуально-личностных до социокультурных» [Изотова, Полева, 2017, с. 159].

Образное осмысление окружающей действительности, основанное на ассоциативном мышлении и художественном восприятии мира, включающем эстетический, эмоциональный и этический аспекты, можно рассматривать как один из способов познания. Мировоззрение человека, существующего в определенном культурном пространстве, обусловливает появление тех или иных художественных образов, формирующих художественную картину мира, представленную произведениями искусства в области литературы, живописи, музыки, кино, театра и возникающую на основе их восприятия и под воздействием искусствоведческих исследований и критических работ [Миниханова, Фаткуллина, 2012].

Оперируя термином «художественная картина мира», мы основываемся на исследованиях таких ученых, как Ю.М. Лотман [1981], Б.С. Мейлах [1983], П.В. Соболев [1986] и др., определяющих гносеологический и мировоззренческий потенциал данного понятия. Однако важно учитывать и эстетический аспект художественной картины, что следует из ее дуалистической сущности, объединяющей философское и творческое начала.

Наиболее значимыми для настоящей работы представляются изыскания [Лотман, 1981; Топоров, 1983; Успенский, 1995], раскрывающие коммуникативную природу художественных произведений, семиотическая интерпретация которых является ключом к по- 
ниманию художественных картин, фиксирующих индивидуальную концептосферу субъекта-творца. «... Художественная картина мира связана с картиной мира личности, которая формируется воздействием социальной среды и на основе взглядов, задаваемых жизненным рядом» [Мусат, 2015, с. 2].

Взаимосвязь когнитивных процессов и процесса формирования «художественной модели», рассматриваемая в работах Р.И. Павилениса [1986], Ю.Н. Караулова [1987], В.В. Красных [2001, 2002] и многих других ученых, раскрывается наиболее полно при исследовании художественных образов, созданных на основе языковых средств, где происходит слияние двух опосредованных картин: художественной и собственно языковой. «Мировоззрение субъекта литературного творчества в процессе создания художественного произведения трансформируется в художественную модель мира - такую же ментальную единицу, которая актуализуется в художественном тексте посредством набора художественных форм» [Воронина, 2008]. Следовательно, художественный текст представляет собой «хранилище» авторских замыслов, воплощенных в языковые формы, когнитивно-семантическая интерпретация которых позволяет выявить особенности субъективного видения мира и опыта личности писателя или поэта и определить особенности его концептосферы, в основе которой лежит определенный набор индивидуально-авторских концептов. В.А. Пищальникова представляет художественный текст в виде набора «эстетических речевых актов», репрезентирующих концептуальную систему писателя [Пищальникова, 1999, с. 4]. Таким образом, художественный текст характеризуется наличием концептов, которые, оставаясь ментальными сущностями, в литературном произведении становятся крайне субъективными и метафоричными, что позволяет определять их как индивидуально-авторские художественные концепты. Такие концепты «не стремятся к тождественности с объективным миром, а «достраивают» его с помощью мифических и субъектно-оценочных категорий, становясь шире и больше самого отражаемого мира» [Микешина, 2002, с. 505].

Однако несмотря на активное изучение природы художественного концепта, методов его исследования и способов выражения, единый подход к решению проблемы отсутствует. Дискуссионными остаются вопросы о структуре индивидуально-авторского концепта и возможности его моделирования, о соотношении концепта и его репрезентаций, взаимосвязи концепта и значения языковых единиц, его объективирующих. Многочисленные исследования недостаточны для полного раскрытия своеобразия авторской философии, мировоззрения творческой личности, касающиеся, прежде всего, особой концепции мира и места человека в нем. Исследование художественного концепта невозможно без анализа текста как целостной системы, то есть самоценного эстетического явления. Одним из важнейших аспектов такого анализа является определение закономерностей организации языковых средств в конкретном художественном тексте и их роли в выражении индивидуально-авторских концептов мировоззрения писателя.

В связи с этим цель работы, которая заключается в моделировании образного компонента концепта «война», признаки которого в художественном произведении несут «основную и в большей степени явную мировоззренческую нагрузку» [Воронина, 2008], отражают особенности идиостиля французского писателя и его отношение к исследуемому социальному явлению, видится достаточно значимой в межцивилизационном аспекте с точки зрения овладения выразительными средствами французского языка для их использования в межкультурной коммуникации при выражении конкретной мировоззренческой позиции. Достижению указанной цели способствует решение следующих задач: 1) выявление состава единиц номинативного поля индивидуально-авторского концепта «война», участвующих в формировании его образного компонента; 2) анализ контекстуального значения языковых средств, репрезентирующих рассматриваемый концепт в новеллах М. Дрюона; 3) описание эксплицитных и имплицитных образных признаков; 4) определение особенностей идиостиля французского автора и его этической позиции по отношению к войне. 


\section{Объекты и методы исследования}

Объектом настоящего исследования являются художественные тексты новелл французского писателя Мориса Дрюона, сюжет которых разворачивается во время Второй мировой войны. В качестве предмета исследования выступают признаки образного компонента концепта «война», выявляемые в результате когнитивно-семантического и контекстуального анализа вербализующих его средств и отражающие этическую позицию французского писателя.

Методологической базой исследования послужили работы в области когнитивной лингвистики и лингвокультурологии, одним из принципов которых является комплексный подход к изучению концептосферы, предполагающий структурирование национальной языковой картины мира на основании лингвокультурологического и когнитивного анализа [Апресян, 1995; Алефиренко, 2006; Болдырев, 2000], а также труды, посвященные изучению индивидуально-авторского концепта. Понятие индивидуально-авторского концепта осмысляется в его многочисленных трактовках современными учеными. Так, О.Е. Беспалова определяет данное явление как «единицу сознания поэта или писателя, которая получает свою репрезентацию в художественном произведении или совокупности произведений и выражает индивидуально-авторское осмысление сущности предметов или явлений» [Беспалова, 2002, с. 6]. Л.В. Миллер, рассматривая индивидуально-авторский концепт, делает акцент на его принадлежности «психоментальной сфере определенного этнокультурного сообщества» и отождествляет его с «художественным опытом, зафиксированным в культурной памяти» и способным участвовать в формировании «новых художественных смыслов» [Миллер, 2000, с. 41]. Н.Г. Горбунова [2006] предлагает понимать такой концепт как единицу индивидуального сознания, авторской концептосферы, вербализованную в едином тексте творчества писателя. Однако несмотря на разнообразие существующих дефиниций, общим остается признание того, что индивидуально-авторский концепт всегда отражает мировоззренческую позицию писателя, формирование которой обусловливается прежде всего условиями формирования личности автора. Соответственно, чтобы раскрыть индивидуально-авторский концепт, необходимо познакомиться с личностью человека, создающего неповторимые образы и рисующего уникальные картины посредством языка.

\section{Результаты и их обсуждение}

Морис Дрюон, чьи произведения являются объектом настоящего исследования, уроженец Парижа, но его предками были известные в дореволюционном Оренбурге купцы. Большое влияние на становление Дрюона оказал его дядя по отцовской линии, писатель Иосиф Кессель. Склонность к литературному творчеству проявилась у Мориса еще в школьные годы. О взглядах М. Дрюона позволяют судить такие факты его биографии, как обучение в школе кавалерийского искусства, получение образования на литературном факультете, участие в движении Сопротивления в годы Второй мировой войны, а также в освободительном движении в качестве военного корреспондента. Наибольшую известность Дрюону-писателю принесли исторические романы из серии «Проклятые короли» и трилогия «Конец людей». Являясь искренним патриотом Франции и приверженцем идей Шарля де Голля, Морис Дрюон свои антибуржуазные взгляды выражает с помощью художественных образов в собственной неповторимой манере. Стремясь предельно беспристрастно и объективно изобразить общественные пороки, автор не остается абсолютно отстраненным, читатель всегда чувствует отношение писателя к персонажам и к тому, что с ними происходит. По мнению критиков [Ерофеева, 2013], реализм в творчестве М. Дрюона часто достигается за счет натуралистического описания деталей, бытовых подробностей, которые дают возможность интерпретировать создаваемые образы. Для творческой манеры французского писателя характерны также использование несобствен- 
но-прямой речи и способность посмотреть на все глазами героев произведений. Но своеобразие авторского стиля М. Дрюона было сформировано под воздействием его предшественников, и поэтому в его книгах, как и в других реалистических романах, может содержаться «...иногда подтекст, а иногда страстное, прямое выражение авторских взглядов; иногда публицистика, врывающаяся в действие, а иногда такое молчание, которое действует сильнее призыва» [цит. по: Максимов, 1975].

По мнению Е.А. Ворониной, к художественным формам выражения мировоззрения писателя относятся «художественная модель мира, художественный концепт и система художественных образов», «посредством которых в метафорической форме до читателя доходит авторский замысел, пронизанный идеей и мировоззренческими установками личности творца» [Воронина, 2008]. Исследуя концепт «война», в частности его образную составляющую, реконструированную с помощью определенных языковых средств в произведениях М. Дрюона, мы можем получить фрагментарное представление об индивидуально-авторской языковой и художественной картинах мира французского писателя.

Анализируя языковые средства, вербализующие исследуемый концепт в новеллах Мориса Дрюона из серии «Повелители просторов», следует, прежде всего, отметить, что автор в своих произведениях, описывающих события, происходящие во время Второй мировой войны, очень редко использует ключевую лексему guerre (война): ma petite guerre (моя маленькая война), la fin de la guerre (конец войны), la guerre ne l'intéressait pas (война его не интересовала). Нельзя назвать частым и употребление принадлежащих ядерной зоне номинативных единиц troupes, $f$ (войска), armée, $f$ (армия), peloton, $m$ (взвод), ligne de fеи (линия огня), avant-poste, $m$ (форпост), militaire (военный), divisionnaire (дивизионный) и т.д.

Языковые единицы, вербализующие образные признаки индивидуально-авторского концепта «война», принадлежащие ядру или приядерной зоне соответствующего номинативного поля, условно можно разделить на три основные группы: 1) лексемы, обозначающие воинское звание: maréchal, $m$ (маршал), colonel, $m$ (полковник), lieutenant-colonel, $m$ (подполковник), général, $m$ (генерал), commandant, $m$ (командир, майор), officier, $m$ (офииер), sous-officier, $m$ (унтер-офицер, сержант), саріtaine, $m$ (капитан, командир роты), оrdonnance, $m$ (денщик), soldat, $m$ (солдаm); 2) слова, называющие боеприпасы и военные орудия: torpille, $f$ (мина), grenade, $f$ (граната), balle, $f$ (пуля), оbus, $m$ (снаряд, минометная мина), bombe, $f$ (бомба), pistolet, $m$ (пистолет), fusil (m) mitrailleur (ручной пулемет), mousqueton, $m$ (карабин), mitraillette, $f$ (автомат); 3) кавалерийская лексика: uhlan, $m$ (улан), sabre, $m$ (сабля), lance (пика), stick, $m$ (хльст), gие̂tres, $f$ (краги), escadron, $m$ (эскадрон), cavalerie, f (кавалерия, конница), cavalier, $m$ (кавалерист), е́реron, $m$ (ипора) и т.д.

Все перечисленные выше языковые единицы в определенном контексте эксплицитно участвуют в создании образов, возникающих благодаря непосредственному восприятию объектов органами чувств.

Лексемы, представленные в первой группе, как правило, позволяют «нарисовать» фрагменты фронтовых будней, участниками которых являются люди, одетые в военную форму и выполняющие определенные действия. При этом отсутствие четкого представления о знаках различия представителей французской армии может приводить к несколько размытым картинам, но, на наш взгляд, это не мешает воплощению авторского замысла и передаче атмосферы накаленности и тревоги, страха и мужества.

Например, в следующем отрывке читатель видит военных, изучающих карту и, видимо, разрабатывающих стратегию. Их сосредоточенность, напряженность выражается, прежде всего, с помощью глаголов: "...le général était là, penché sur une carte, avec une demi-douzaine d'officiers supérieurs autour de lui. $<\ldots>$. Un malheureux sous-officier tapait sur une machine à écrire, à s'en casser les doigts; les plantons entraient, sortaient" [Druon, 1975, p. 160] (Генерал был у себя: он изучал карту, а вокруг него столпились человек шесть офищеров. <...>. Младиий офищер быстро строчил на пишущей машинке, отбивая 
себе пальиь; взад-вперед сновали дневальные) (здесь и далее перевод О. Егоровой, Л. Ефимова, С. Васильевой) [Дрюон, 2010, с. 95]. Благодаря контексту возникают и визуaльныле образы подполковника и капитана французской армии, храбрость и невозмутимость которых при общей панике во время вражеской бомбардировки вызывает восхищение: "Les hommes aperçurent le lieutenant-colonel, debout, très raide, mais qui tapotait nerveusement son mollet avec son stick; à côté de lui le capitaine de Navailles observait les bombardiers à la juтelle" [Druon, 1975, p. 173] (Бойць увидели подполковника, который стоял очень прямо и нервно постукивал хлыстом по сапогу. Рядом с ним капитан де Навей наблюдал за бомбардировщиками в бинокль) [Дрюон, 2010, с. 64]. Рассмотрим еще один пример: "Le soldat qui se remettait debout, ne comprenait pas très bien quel choix avait été fait, ni pourquoi son camarade à côté ne remuait pas. Un fou courait en rond, autour d'un écheveau de side-cars emmêlés" [Druon, 1975, p. 175] (Какой-то обезумевший солдатик вскочил на ноги, таки не успев понять ни того, что выбор уже сделан, ни того, что его товарищ рядом уже никогда не сможет пошевелиться. Он принялся носиться вокруг клубка бесформенного металла, который недавно был мотоциклами) [Дрюон, 2010, c. 66]. Образ солдата, пережившего ужас авианалета, раскрывается не только за счет использования глаголов движения se remettre debout (подняться на ноги), courir en rond (бегать по кругу), описывающих действия военного, но и за счет лексем, значение которых указывает на когнитивные способности: ne pas comprendre (не понимать) и fou (сумасшедший, обезумевший). Именно такое контекстуальное воплощение не просто изображает персонаж, но и передает его душевное смятение, ошеломление.

Номинативные единицы, обозначающие военные орудия, оружие и боеприпасы, всегда эксплицитно участвуют в формировании зрительных образов в любом контексте: "...son colt sur le ventre, bien au milieu du ceinturon" [Druon, 1975, p. 193] (кольт на животе, как раз посередине ремня); "...ce cavalier arrivant sur lui, le sabre en avant" [там же, p. 191] (всадник, несущийся на него с саблей наголо); "...faites-moi donc approcher une caisse de grenades" [там же, p. 165] (поднесите мне ящик с гранатами) и т.д.

Но у художника слова, М. Дрюона, такие визуальные образы становятся особенно яркими и живыми благодаря метафорам. В следующих примерах рассматриваемые лексемы участвуют в создании визуальных метафорических образов, включаясь в контекст пулеметные и автоматные очереди вырисовывают орденскую цепь на груди солдата, подметают землю, покрывают дом звездочками: "Une giclée de balles lui avait dessiné un collier rouge, sur la poitrine" [там же, p. 175] (Автоматная очередь прочертила на его груди красную полосу, совсем как орденскую цепь) [Дрюон, 2010, с. 66]; "A ce moment une nouvelle décharge de mitraillette balaya le terrain..." [Druon, 1975, p. 188] (В этот момент по мостовой снова полоснула пулеметная очередь (букв. «подмела землю»)) [Дрюон, 2010, с. 81]; "... иne troisième volée de balles étoila la façade" [Druon, 1975, p. 188] (...третья пулеметная очередь покрыла фасад дома звездочками сколов) [Дрюон, 2010, с. 81].

Акустические образы автор передает, сочетая лексемы, обозначающие орудия и снаряды, с глагольными формами: "...les fusils mitrailleurs commençaient à claquer (cлblщaлось клачанье автоматов)" [Druon, 1975, p. 187; Дрюон, 2010, с. 79]; "Quand il entendait une bombe descendre un peu trop près, La Marvinière rentrait légèrement la tête dans les épaules... (Когда он слышал свист бомбы слишком близко, то слегка втягивал голову в плечи...)" [Druon, 1975, p. 161; Дрюон, 2010, с. 97]. Это могут быть звуки войны, возникающие не только на основе непосредственного чувственного восприятия, но и на основе ассоциативного мышления, что довольно часто у М. Дрюона репрезентируется с помощью сравнительных оборотов и конструкций. Особая образность, характеризуемая повышенной эмоциональностью и яркостью, создается иногда с помощью так называемого отрицательного сравнения: "Ce crépitement qui recommençait, cherchant les cailloux sous les plantes, n'avait que peu de rapport avec les expressions traditionnelles de comparaison; la crécelle, ou le moulin à café. Cela pouvait être aussi bien la batteuse quand elle s'affole en brisant les épis, 
ou bien une grêle géante battant contre les vitres de la vie, ou encore le bruit monstrueusement grossi d'une feuille de papier qu'on déchire" (Треск, который затем раздался, не подпадал ни под одно сравнение, которые обычно приводят для его описания. Его нельзя было сравнить ни с трещзоткой, ни с кофейной мельницей. Он скорее походил на грохот взбесившейся молотилки. Звук был такой, словно гигантская муха билась о стекло (в оригинале «гигантский град») или кто-то рвал на части огромный лист бумаги) [Druon, 1975, p. 171; Дрюон, 2010, с. 61]. Психологический накал, запредельность всего происходящего во время вражеского авиаудара выражается в приведенном фрагменте посредством противопоставления более привычных звуков трещотки и кофейной мельницы грохоту молотилки и ударам гигантских градин. Усиление впечатления от атаки достигается за счет олицетворения: молотилку автор наделяет вызывающей страх способностью человека сходить с ума, беситься. Анализ образных сравнений на семантическом уровне позволяет выявить дополнительные средства, отражающие оригинальную авторскую манеру [Васry, 1992; Cazelles, 1996; Robrieux, 1993]. Читателю новелл М. Дрюона «услышать» ужас, испытываемый человеком во время бомбардировки, помогают лексемы, звуковая семантика которых обусловливает их материальное воплощение (batter - бить, колотить, briser - бить, дробить, crépitement - треск, la crécelle - трещотка), а также языковые единицы, имеющие семы gros, grand, excessif (grossir - увеличивать, раздувать, géant - гигантский, исполинский, monstrueusement - чрезмерно, непомерно) [TLF, 1986].

Характерной особенностью номинативного поля концепта «война» в художественной картине М. Дрюона является, на наш взгляд, наличие в нем достаточно большого количества кавалерийской лексики, также участвующей в создании наглядно-чувственных образов. Скорее всего, это следствие кавалерийского прошлого самого писателя, окончившего специальную школу, где он обучался верховой езде. Данную группу языковых единиц можно отнести к приядерной зоне исследуемого концепта, так как, несмотря на то, что кавалерия хоть и является одним из видов войск, в современном мире она все реже ассоциируется с военными действиями. Но М. Дрюон даже эскадрон мотоциклов описывает так, как будто речь идет о конных войсках, что, как нам кажется, позволяет ему противопоставить жестокости и вероломству фашистов благородство и мужественность французских солдат.

Но художнику, чтобы описать войну, совсем не обязательно использовать слова, имеющие к этой теме непосредственное отношение. В авторском исполнении образные признаки исследуемого концепта репрезентируются с помощью языковых единиц, не входящих в соответствующее номинативное поле. Однако именно с их помощью мы получаем наиболее яркие картины, построенные на всех видах чувственного восприятия (акустическом, визуальном, обонятельном, осязательном), при этом большинство образов создается с помощью метафор и сравнений: les vrombissements, dans l'espace, parurent du silence (тишину прорвал шум моторов); les autres, entre les coups du sol, entendaient les coups accélérés de leur sang (в ушах остальных между ударами, разрывающими землю, звенели бешеные удары собственных сердец); la langue gutturale (гортанный язык); un crépitement courut sur le sol (земля затрещала); cent trente cris sans voix (сто тридцать беззвучных криков); un avion fondre sur lui (пикирующий самолет); deux cents voitures en pagaïe dans le village (в деревне сотни две автомобилей брошены в беспордке); un muret à moitié en ruine (обвалившаяся стена); le sol fumait (земля дымилась); les branches étaient mêlées à l'acier, aux étoffes, à la chair (ветви смешались с кусками металла, ткани человеческой плоти); masques de tragédie (трагические маски); les visages, brûlants de poussière et de vent (обожженные солнцем, обветренные лица); sous cette tornade de métal (в этом вихре металла); les quinze avions au-dessus des arbres continuaient leur ballet noir (над деревьями пятнадцать самолетов продолжали свою пляску смерти); odeur de formol, d'éther et de ligne souillé (запах формалина, эфира и грязного белья); la mauvaise senteur (скверный запах); des étincelles de la douleur (вспышки боли); le bruit les jeta contre terre (оглушительный грохот 
опрокинул их на землю); ils attendirent l'écrasement àla fin de ce tonnerre vertical (все ждали, что грохот завершится взрывом); un cri stupéfait de blessé (изумленный крик раненого); la terre furieuse qui sautait sous eux, qui les rejetait (взбесившаяся земля, которая ходила под ними ходуном, не желая их принимать); l'os de la jambe s'était ouvert comme une fleur de lis (кость на ноге раскрылась как цветок лилии) и т.д. [Druon, 1975; Дрюон, 2010].

Следует отметить, что довольно часто у Дрюона созданные им предметные образы имплицитно отражают внутреннее состояние человека, подвергшегося ужасам войны, его страх, панику (une crispations de l'épigastre - неприятный холодок под ложечкой); Serval était devenu très pale, et sa main tremblait - Серваль побледнел, рука его задрожала), сумасшествие, неприятие всего происходящего (la possibilité de penser en mots s'était arrêtée - способность мыслить словами начисто отшибло; affolement, les hommes à plat ventre dans les jardins - началась паника, и люди попадали ничком на землю), отчаяние и разочарование (la stupide humidité des larmes - глупая сырость нежданных слез; rien qu'un immense mur gris - ничего, кроме огромной серой стены), надежду (les hommes espéraient sauvegarder leur cerveau, leur conscience - люди надеялись сохранить свой мозг, свое сознание) [Druon, 1975; Дрюон, 2010]. Мы полагаем, что все эти абстрактные понятия в творчестве французского писателя символизируют войну и тоже становятся ее образами.

\section{Заключение}

Художественный концепт - это основообразующая единица индивидуальноавторской картины мира, исследование которой позволяет раскрыть особенности восприятия окружающей действительности творческой личностью, которая выражает свой взгляд на мир, создавая определенные художественные формы. Оригинальность авторского концепта «война» М. Дрюона прослеживается как на уровне номинативного поля концепта, так и на содержательном и структурном уровнях. Образный компонент абстрактного концепта «война» в новеллах французского писателя раскрывается не только эксплицитно с помощью предметных наглядно-чувственных «картинок», но и имплицитно с помощью контекстуальных метафор, сравнительных оборотов и символов. При этом символы часто являются абстрактными.

Языковые средства, используемые автором при создании образов войны, в большинстве случаев свидетельствуют о его склонности к натурализму. Кавалерийская лексика демонстрирует желание писателя создать атмосферу военного аристократизма и героизма, однако при этом читатель может почувствовать и некоторую наивность французской армии, ее неспособность принять новую реальность. Художественные образы, «рисующие» войну, строятся и на основе военной терминологии, и с помощью слов, не имеющих непосредственного отношения к данной теме, например, с помощью театральной, медицинской, бытовой лексики.

Описывая войну, писатель почти не касается образа врага, враг обезличен и появляется на расстоянии в качестве мишени или как невидимая угроза. Образ французского солдата, напротив, представлен достаточно выразительно. Продемонстрированные примеры позволяют читателю почувствовать стремление автора противопоставить мужество и благородство отдельно взятой личности панике, охватывающей толпу. Смелость и способность не терять веру в свои силы - это то, что дает надежду, что заставляет продолжать борьбу. Но изолированный образ французского солдата служит средством выражения авторского замысла, только вступая во взаимосвязь с другими образами. Именно целостное восприятие всей системы художественных образов, созданных в рассмотренных новеллах, отражает совершенно четкую позицию Мориса Дрюона, для которого война - это хаос, безумие, отчаяние, разруха, страдание, боль и смерть.

Таким образом, в нашем исследовании мы впервые попытались представить модель образного компонента концепта «война» в концептосфере Мориса Дрюона, ядром 
которого являются ассоциативные метафорические признаки «хаос» и «смерть». Лингвоконцептуальная информация представлена в художественных текстах писателя не столько посредством ключевых лексем, сколько с помощью разнообразных стилистических приемов, наиболее распространенными из которых являются авторские сравнения, метафоры, олицетворение и противопоставление с опорой на все виды чувственного восприятия и с подробным описанием физиологических деталей.

Результаты исследования значимы с точки зрения овладения выразительными средствами французского языка для их использования в межкультурной коммуникации при выражении конкретной мировоззренческой позиции.

\section{Список источников}

1. Азимов Э. Г., Щукин А.Н. 2009. Новый словарь методических терминов и понятий (теория и практика обучения языкам). Под ред. Э.Г. Азимова, А.Н. Щукина, М., Издательство ИКАР, $448 \mathrm{c}$.

2. Безрукова В.С. 2000. Основы духовной культуры (энциклопедический словарь педагога). Екатеринбург, 937 с.

3. Дрюон М. 2010. Такая большая любовь. Пер. с фр. О. Егоровой, Л. Ефимова, С. Васильевой. М., Эксмо; СПб., Домино, 400 с. (Druon M. 1967. Le bonheur des uns. Plon, 342 p.)

4. Ерофеева Н.Е. 2013. Дрюон Морис. Новая Российская Энциклопедия: в 12 т. Т. VI (1) Дрейк - Зеленьский. Под ред. А.Д. Некипелова. Москва, Энциклопедия: ИД ИНФРА-М, 480 с.

5. Дрюон М. 1975. Рассказы = Nouvelles. Под ред. Л.Ю. Виндт. Л., «Просвещение», 221 с.

6. TLF - Trésor de la langue française. Dictionnaire de la langue du XIX-e et XX-e s. 1986. Paris: Gallimard. URL: https://www.cnrtl.fr/definition/monstrueusemen (accessed: 23 March 2020).

\section{Список литературы}

1. Апресян Ю.Д. 1995. Избранные труды. Том II. Интегральное описание языка и системная лексикография. М., Языки русской культуры, 768 с.

2. Алефиренко Н.Ф. 2006. Язык, познание и культура: когнитивно-семиологическая синергетика слова. Волгоград, Перемена, 228 с.

3. Беспалова О.Е. 2002. Концептосфера поэзии Н.С. Гумилева в ее лексическом представлении. Автореф. дис. ...канд. филол. наук. СПб., 24 с.

4. Болдырев Н.Н. 2000. Когнитивная семантика. Тамбов, Изд-во ТГУ им. Г.Р. Державина, $123 \mathrm{c}$.

5. Воронина Е.А. 2008. Основные формы выражения индивидуально-авторского мировоззрения в литературном творчестве. Вестник Нижегородского университета им. Н.И. Лобачевского. Серия: Социальные науки, 1 (9): 158-163.

6. Горбунова Н.Г. 2006. Языкотворчество Дж. Джойса: словообразовательный аспект (на примере романа «Улисс»). Дис. ...канд. филол. наук. СПб., 204 с.

7. Изотова Е.И., Полева Н.С. 2017. Роль культуры и искусства в формировании современных подростков. Мир психологии, 2 (90): 158-166.

8. Караулов Ю.Н. 1987. Русский язык и языковая личность. Под ред. Д.Н. Шмелева. М., Наука, 261 с.

9. Красных В.В. 2001. Основы психолингвистики и теории коммуникации. М., ИТДГК «Гнозис», $270 \mathrm{c}$.

10. Красных В.В. 2002. Этнопсихолингвистика и лингвокультурология. М., ИТДГК «Гнозис», 283 с.

11. Лотман Ю.М. 1981. Риторика. В кн. Труды по знаковым системам. Т. 12: Структура и семиотика художественного текста. Ученые записки Тартуского ун-та, Вып. 515: 8-28.

12. Максимов Э.Н. 1975. Элементы драмы в историческом романе современной Франции (М. Дрюон, П. Гамарра, Ж.-П. Шаброль). В кн. К проблемам романтизма и реализма в зарубежной литературе конца XIX-XX веков. М., 148-155.

13. Мейлах Б.С. 1983. Философия искусства и художественная картина мира. Вопросы философии, 7: 116-125. 
14. Микешина Л.А. 2002. Философия познания. Полемические главы. М., ПрогрессТрадиция, $624 \mathrm{c}$.

15. Миллер Л.В. 2000. Художественный концепт как смысловая и эстетическая категория. Мир русского слова, 4: 39-45.

16. Миниханова Л.К., Фаткуллина Ф.Г. 2012. Художественная картина мира как особый способ отражения действительности. Вестник Башкирского Университета, 3: 1626-1627.

17. Мусат Р.П. 2015. Художественная картина мира: принципы взаимосвязи формы и содержания. Теория и практика общественного развития, 17: 163-166.

18. Пищальникова В.А. 1999. Психопоэтика. Барнаул, Изд-во Алт. гос. унта, 173 с.

19. Соболев П.В. 1986. Художественная культура личности. Л., Знание, 32 с.

20. Топоров В.Н. 1983. Пространство и текст. В кн. Текст: семантика и структура. Под ред. Т.В. Цивьян. М., Наука: 227-284.

21. Успенский Б.А. 1995. Семиотика искусства. Серия: Язык. Семиотика. Культура. М., Школа «Языки русской культуры», 360 с.

22. Bacry P. 1992. Les figures de style: et autres procédés stylistiques. Paris, Belin, coll. «Collection Sujets», 335 p.

23. Cazelles N. 1996. Les comparaisons du français. Paris, Belin, coll. Le français retrouvé, 333 p.

24. Robrieux J. J. 1993. Des tropes ou des differents sens [Tropes or different senses]. Paris, 241 p.

\section{References}

1. Apresyan Yu.D. 1995. Izbrannye trudy [Selected Works]. Vol. II. Integral'noe opisanie yazyka i sistemnaya leksikografiya [Integral description of the language and systemic lexicography]. M., Publ. Yazyki russkoy kul'tury, $768 \mathrm{p}$.

2. Alefirenko N.F. 2006. Yazyk, poznanie i kul'tura: kognitivno-semiologicheskaya sinergetika slova [Language, Cognition and Culture: Cognitive-Semiological Synergetics of the Word]. Volgograd, Publ. Peremena, $228 \mathrm{p}$.

3. Bespalova O.E. 2002. Kontseptosfera poezii N.S. Gumileva v ee leksicheskom predstavlenii [The concept of poetry by NS Gumilyov in her lexical presentation]. Abstract. dis. ... cand. philol. sciences. $\mathrm{SPb} ., 24 \mathrm{p}$.

4. Boldyrev N.N. 2000. Kognitivnaya semantika [Cognitive semantics]. Tambov, Publ. Izd-vo TGU im. G.R. Derzhavina, 123 p.

5. Voronina E.A. 2008. Osnovnye formy vyrazheniya individual'no-avtorskogo mirovozzreniya v literaturnom tvorchestve [The main forms of expression of the individual author's worldview in literary creation]. Vestnik of Lobachevsky State University of Nizhni Novgorod. Series: Social Science, 1 (9): $158-163$.

6. Gorbunova N.G. 2006. Yazykotvorchestvo Dzh. Dzhoysa: slovoobrazovatel'nyy aspekt (na primere romana «Uliss») [Linguistic creativity of J. Joyce: word-formation aspect (on the example of the novel "Ulysses")]. Dis. ... cand. philol. sciences. SPb., 204 p.

7. Izotova E.I., Poleva N.S. 2017. Rol' kul'tury i iskusstva $v$ formirovanii sovremennykh podrostkov [The role of culture and art in the formation of modern adolescents]. Mir psikhologii, 2 (90): $158-166$.

8. Karaulov Yu.N. 1987. Russkiy yazyk i yazykovaya lichnost' [Russian language and language personality]. Ed. D.N. Shmeleva. M., Publ. Nauka, 261 p.

9. Krasnykh V.V. 2001. Osnovy psikholingvistiki i teorii kommunikatsii [Fundamentals of Psycholinguistics and Communication Theory]. M., Publ. ITDGK «Gnozis», 270 p.

10. Krasnykh V.V. 2002. Etnopsikholingvistika i lingvokul'turologiya [Ethnopsycholinguistics and cultural linguistics]. M., Publ. ITDGK «Gnozis», 283 p.

11. Lotman Yu.M. 1981. Ritorika [Rhetoric]. In: Trudy po znakovym sistemam [Proceedings on sign systems]. Vol. 12: Struktura i semiotika khudozhestvennogo teksta [Structure and semiotics of literary text]. Uchenye zapiski Tartuskogo un-ta, Vyp. 515: 8-28.

12. Maksimov E.N. 1975. Elementy dramy v istoricheskom romane sovremennoy Frantsii (M. Dryuon, P. Gamarra, Zh.-P. Shabrol') [Elements of drama in the historical novel of modern France (M. Druon, P. Gamarra, J.-P. Chabrol)]. In: K problemam romantizma i realizma v zarubezhnoy literature kontsa XIX-XX vekov [To the problems of romanticism and realism in foreign literature of the late 19th20th centuries]. M., 148-155. 
13. Meylakh B.S. 1983. Filosofiya iskusstva i khudozhestvennaya kartina mira [Philosophy of Art and Artistic Picture of the World]. Voprosy filosofii, 7: 116-125.

14. Mikeshina L.A. 2002. Filosofiya poznaniya. Polemicheskie glavy [Philosophy of Knowledge. Polemic chapters]. M., Publ. Progress-Traditsiya, 624 p.

15. Miller L.V. 2000. Khudozhestvennyy kontsept kak smyslovaya i esteticheskaya kategoriya [Artistic concept as a semantic and aesthetic category]. The World of Russian Word, 4: 39-45.

16. Minikhanova L.K., Fatkullina F.G. 2012. Khudozhestvennaya kartina mira kak osobyy sposob otrazheniya deystvitel'nosti [An artistic picture of the world as a special way of reflecting reality]. Vestnik Bashkirskogo Universiteta, 3: 1626-1627.

17. Musat R.P. 2015. Khudozhestvennaya kartina mira: printsipy vzaimosvyazi formy i soderzhaniya [Artistic picture of the world: principles of the relationship between form and content]. Theory and Practice of Social Development, 17: 163-166.

18. Pishchal'nikova V.A. 1999. Psikhopoetika [Psychopoetics]. Barnaul, Publishing house of the Altai state University, $173 \mathrm{p}$.

19. Sobolev P.V. 1986. Khudozhestvennaya kul'tura lichnosti [The Artistic Culture of the Person]. L., Publ. Znanie, $32 \mathrm{p}$

20. Toporov V.N. 1983. Prostranstvo i tekst [Space and Text]. In: Tekst: semantika i struktura [Space and Text]. Ed. T.V. Tsiv'yan. M., Publ. Nauka: 227-284.

21. Uspenskiy B.A. 1995. Semiotika iskusstva Publ [Semiotics of Art]. Series: Yazyk. Semiotika. Kul'tura [Language. Semiotics. Culture]. M., Publ. Shkola «Yazyki russkoy kul'tury», 360 p.

22. Bacry P. 1992. Les figures de style: et autres procédés stylistiques. Paris, Belin, coll. «Collection Sujets», 335 p. (in French).

23. Cazelles N. 1996. Les comparaisons du français. Paris, Belin, coll. Le français retrouvé, 333 p. (in French).

24. Robrieux J. J. 1993. Des tropes ou des differents sens [Tropes or different senses]. Paris, 241 p. (in French).

\section{ИНФОРМАЦИЯ ОБ АВТОРАХ}

Ломоносова Юлия Евгеньевна, кандидат филологических наук, доцент, доцент кафедры романо-германской филологии и межкультурной коммуникации института межкультурной коммуникации и международных отношений Белгородского национального исследовательского университета, г. Белгород, Россия

Соболева Татьяна Евгеньевна, кандидат филологических наук, доцент, доцент кафедры романо-германской филологии и межкультурной коммуникации института межкультурной коммуникации и международных отношений Белгородского национального исследовательского университета, г. Белгород, Россия

\section{INFORMATION ABOUT THE AUTHORS}

Yulia E. Lomonosova, Candidate of Philology, Associate Professor, Associate Professor of the Department of Romance and Germanic Philology and Intercultural Communication of the Institute of Intercultural Communication and International Relations, Belgorod National Research University, Belgorod, Russia

Tatyana E. Soboleva, Candidate of Philology, Associate Professor, Associate Professor of the Department of Romance and Germanic Philology and Intercultural Communication of the Institute of Intercultural Communication and International Relations, Belgorod National Research University, Belgorod, Russia 